\author{
Article \\ Doi 10.5943/sif/1/1/9 \\ Copyright (C) Mushroom Research Foundation 2016
}

\title{
New records of Phaeoisaria triseptata and Spadicoides heterocolorata for Brazil
}

\author{
Almeida DAC ${ }^{1}$ and Gusmão LFP ${ }^{1}$ \\ ${ }^{1}$ Universidade Estadual de Feira de Santana, Av. Transnordestina, S/N - Novo Horizonte, 44036-900. Feira de \\ Santana, BA, Brazil.
}

Almeida DAC, Gusmão LFP 2016 - New records of Phaeoisaria triseptata and Spadicoides heterocolorata for Brazil. Studies in Fungi 1(1), 99-103, Doi 10.5943/sif/1/1/9

\begin{abstract}
Phaeoisaria triseptata and Spadicoides heterocolorata are described, illustrated and discussed. Both species represent new records for Brazil.
\end{abstract}

Key words - Conidial fungi - hyphomycetes - semi-arid Neotropics

\section{Introduction}

After a survey of conidial fungi performed at the Serra da Fumaça $\left(10^{\circ} 74\right.$ 'S $\left.40^{\circ} 36^{\prime} \mathrm{W}\right)$, Bahia state, in 2008, several new species and new records for Brazil have been reported (Almeida et al. 2011, Almeida et al. 2012, Almeida et al. 2014, Almeida et al. 2015). In this paper, we present two additional records of conidial fungi collected in that area.

\section{Materials \& Methods}

The samples of decaying leaves were placed in paper bags, taken to the laboratory of State University of Feira de Santana and prepared according to Castañeda-Ruiz (2005). Methods for specimen collection, isolation, and morphological examination are described in Almeida et al. (2014). The specimens were deposited in the Herbarium of Universidade Estadual de Feira de Santana (HUEFS).

\section{Results}

Phaeoisaria triseptata Hol.-Jech., Česká Mykol. 42(1): 27.1988.

Figs $1-10$ Syn.: Helicomina triseptata (Hol.-Jech.) R.F. Castañeda, Guarro \& Saikawa, Cryptog. Mycol. 23(1): 16. 2002.

Synnemata straight or flexuous, indeterminate, dark brown at base, pale brown at apex, 17.5$62.5 \mu \mathrm{m}$ wide. Conidiophores caespitose to synnematous, macronematous, simple, cylindrical, erect, straight or flexuous, septate, smooth, brown, arising from a rudimentary pseudoparenchymatous stromata, (75-) 150-475 × 3-5 $\mu \mathrm{m}$. Conidiogenous cells polyblastic, integrated, terminal or intercalary, sympodial, cylindrical, smooth, denticulate, pale brown near base, subhyaline at the apex, splaying out at the apex of the synnemata; denticles conspicuous, cylindrical, truncate at the apex, 2-4 × 1-1.2 $\mu \mathrm{m}$. Secession schizolytic. Conidia solitary, dimorphic, type 1 ellipsoidal to clavate, basal cell conical and pale brown, another cells brown, 


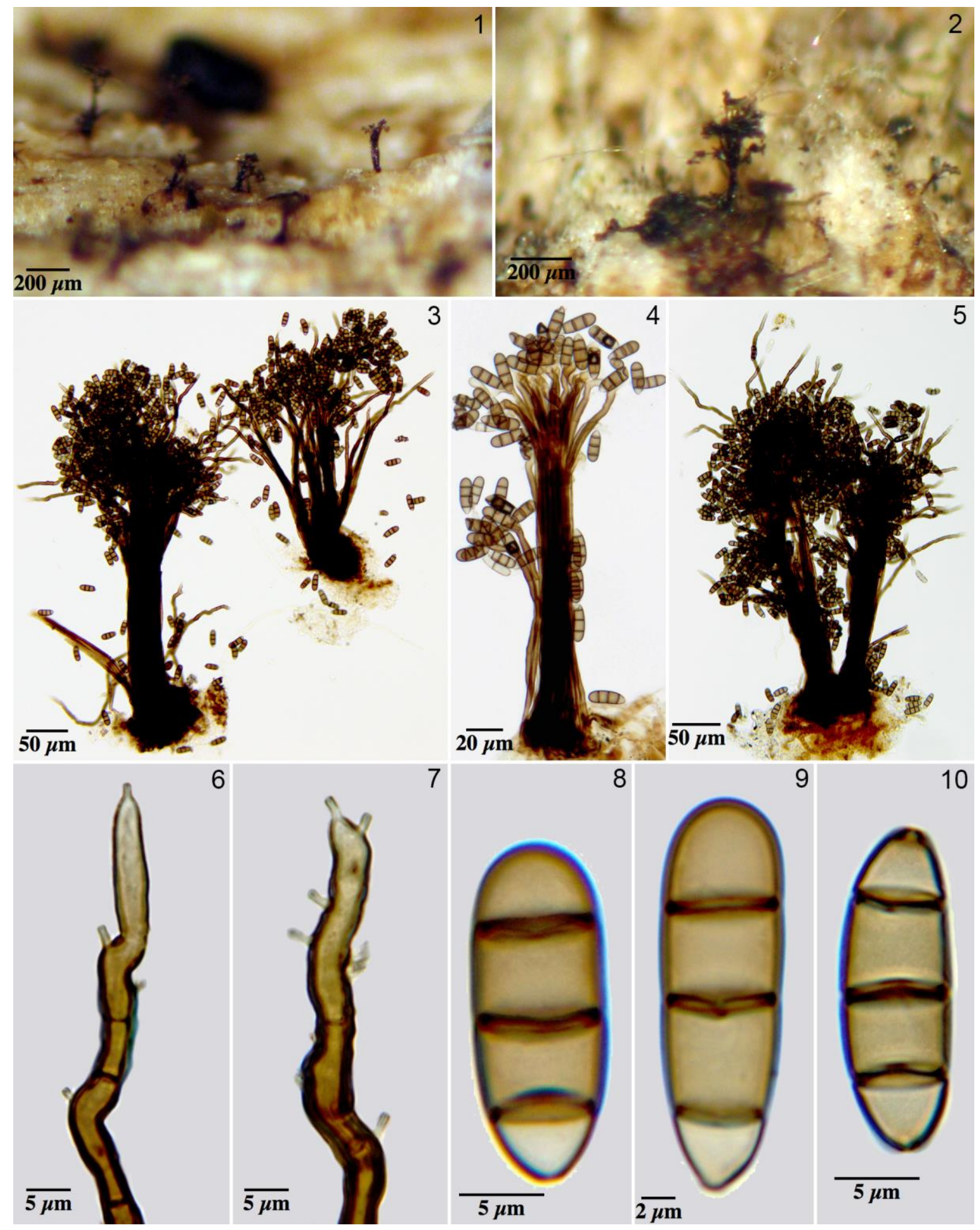

Figs 1-10 - Phaeoisaria triseptata. 1-2 Synnemata on natural substrate. 3-5 General aspect. 6-7 Conidiogenous cells. 8-10 Conidia.

rounded at the apex; type 2 fusiform, basal and apical cells both conical and pale brown, central cells brown; simple, dry, smooth, 3-septate, straight or slightly curved, 16-23 (-29) $\times 6-8 \mu \mathrm{m}$.

Known distribution - Cuba (Holubová-Jechová 1988), USA (Delgado 2009), Puerto Rico (Cantrell et al. 2016), China (Zhang 2012).

Material examined - Brazil, Bahia, Pindobaçu, Serra da Fumaça, on decaying bark of an unidentified plant, 27 Nov 2008, D.A.C. Almeida (HUEFS 155079); 13 Jan 2009, D.A.C. Almeida (HUEFS 155080). 


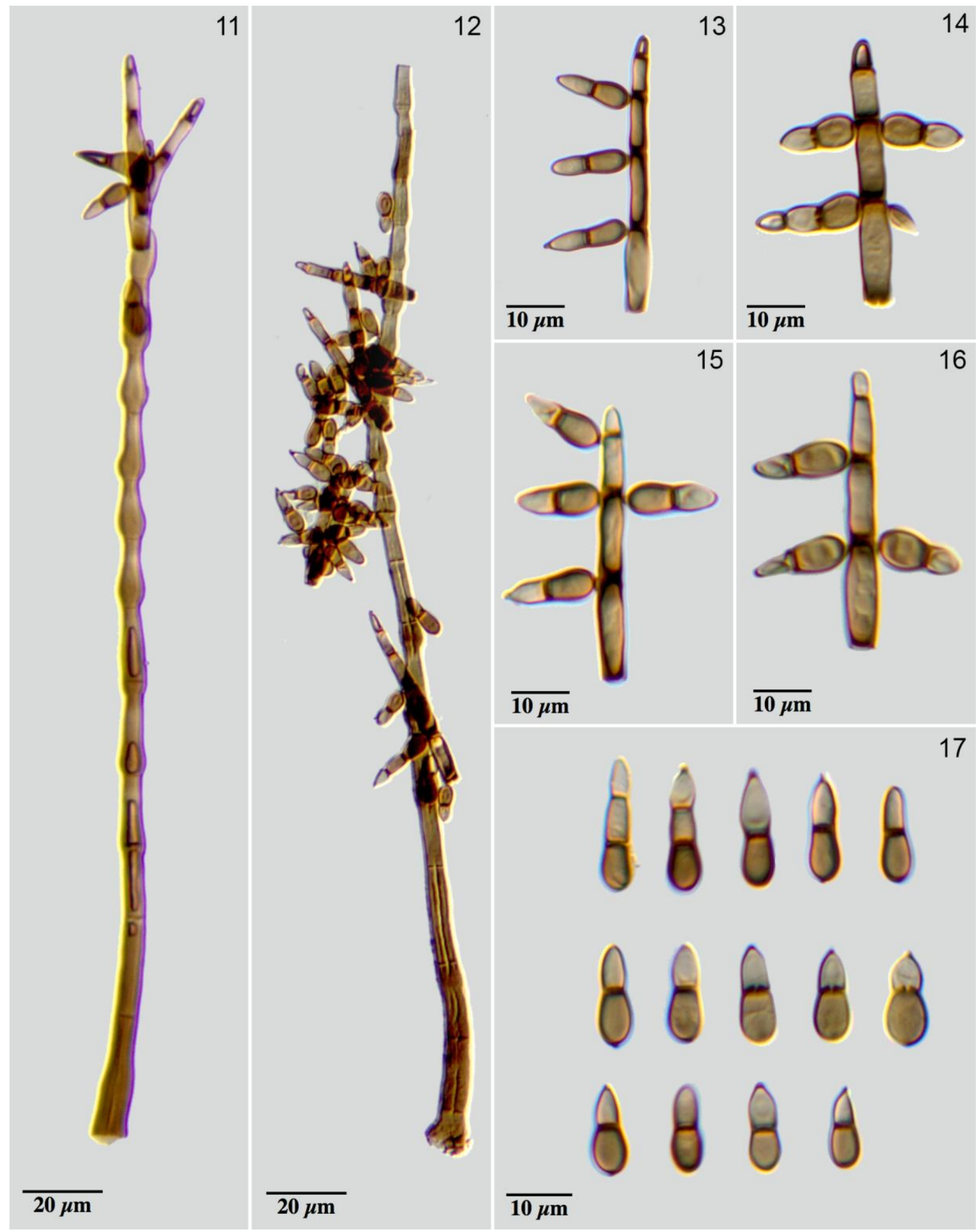

Figs 11-14 - Spadicoides heterocolorata. 11-12 General aspect. 13-16 Conidiogenous cells and conidia. 17 Conidia.

Notes - Phaeoisaria triseptata was transferred to Helicomina L.S. Olive by Castañeda Ruiz et al. (2002). Helicomina, however, was previously considered synonym of Pseudocercospora Speg. by Deighton (1976). On the other hand, this synonymization has not been a consensus (Zhao et al. 2007; Seifert et al. 2011). Alike Delgado (2009) we consider more appropriate keep it in Phaeoisaria until molecular data can elucidate its phylogenetic placement. The Brazilian specimens agree with the original description, except by the shorter conidiophores $(75-475 \mu \mathrm{m}$ versus 600 $1800 \mu \mathrm{m})$ and dimorphic conidia. 
Spadicoides heterocolorata (R.F. Castañeda, Guarro \& Cano) Goh \& K.D. Hyde, Can. J. Bot. 76(10): 1702. 1999.

Figs $11-17$

Bas.: Spadicoides obclavata var. heterocolorata R.F. Castañeda, Guarro \& Cano, Mycotaxon 63: 177. 1997.

Conidiophores macronematous, simple or branched, cylindrical, erect, straight or flexuous, septate, smooth, brown at the base and septa, pale brown toward the apex, the region near septa usually slightly enlarged, except at the basal cells, successively proliferating to form a new apical conidiogenous cell, 248-648 $\times 7-14 \mu \mathrm{m}$. Conidiogenous cells polytretic, integrated, terminal and intercalary, cylindrical, smooth, pale brown. Conidia solitary, obclavate, versicolor, basal cell brown, apical cell pale brown, 1-septate, rarely 2-septate, dry, constricted at septa, 11-21 × 4-6 $\mu \mathrm{m}$. Synanamorph not seen.

Known distribution - Cuba (Castañeda Ruiz et al. 1997).

Material examined - Brazil, Bahia, Pindobaçu, Serra da Fumaça, on decaying leaf of an unidentified plant, 20 Sep 2008, D.A.C. Almeida (HUEFS 192144).

Notes - Spadicoides heterocolorata was proposed as a variety of S. obclavata by Castañeda Ruiz et al. (1997) and after elevated to species rank by Goh \& Hyde (1998). The main differences between them are the conidial septation, mostly 1-septate in the former and mostly 2 -septate in the later, and the presence of an observable protruding hilum in the conidia of the Spadicoides heterocolorata. Goh \& Hyde (1998) also pointed out to justify the combination that there are differences in the microconidial shape and size between the Selenosporella-like synanamorph produced by both species. The Brazilian material, however, did not produce the synanamorph. Our material agrees with the original description except by the conidiophores with region near septa of the upper cells usually slightly enlarged and by absence of the synanamorph.

\section{Acknowledgements}

The authors thank the Program of Research of Biodiversity in the Brazilian Semi-arid (PPBIO Semi-arid/Ministry of Technology and Science - proc. 554718/2009-0) for financial support. The first author thanks the National Council for Scientific and Technological Development for the Postdoctoral Research Fellowships (CNPq proc. 163775/2015-0) and LFPG for the grant (CNPq proc. 303062/2014-2)

\section{References}

Almeida DAC, Barbosa FR, Gusmão LFP. 2012 - Alguns fungos conidiais aquáticos-facultativos do bioma Caatinga. Acta Botanica Brasilica 26, 924-932. doi:http://dx.doi.org/10.1590/S0102-33062012000400021

Almeida DAC, Miller AN, Pascholati Gusmão LF. 2014 - New species and combinations of conidial fungi from the semi-arid Caatinga biome of Brazil. Nova Hedwigia 98 (3-4), 431447. doi:http://dx.doi.org/10.1127/0029-5035/2013/0162

Almeida DAC, Santa Izabel TS, Gusmão LFP. 2011 - Fungos conidiais do bioma Caatinga I. Novos registros para o continente americano, Neotrópico, América do Sul e Brasil. Rodriguésia 62 (1), 43-53.

Almeida DACD, Izabel TDSS, Gusmão LFP, Castañeda-Ruíz RF. 2015 - A new species of Diplococcium from the Brazilian semi-arid region. Mycotaxon 130 (2), 495-498.

Cantrell SA, Lodge DJ, Minter DW, Ortíz OS (2016) Fungi of Puerto Rico. http://www.cybertruffle.org.uk/puerfung/eng/index.htm. Accessed December 222016

Castañeda Ruiz R, Guarro J, Cano J. 1997 - Notes on conidial fungi XII. New or interesting hyphomycetes from Cuba. Mycotaxon 63, 169-181.

Castañeda Ruiz RF, Velasquez S, Cano J, Saikawa M, Guarro J. 2002 - Phaeoisaria aguilerae anam. sp. nov. from submerged wood in Cuba with notes and reflections in the genus Phaeoisaria. Cryptogamie, Micologie 23 (1), 9-18. 
Castañeda-Ruiz R Metodología en el estudio de los hongos anamorfos. In: Anais do V Congresso Latino Americano de Micologia, Brasília, 2005. pp 182-183

Deighton FC. 1976 - Studies on Cercospora and allied genera. VI. Pseudocercospora Speg., Pantospora Cif. and Cercoseptoria Petr. Mycological Papers 140, 1-168.

Delgado G. 2009 - South Florida microfungi: Veramycella bispora, a new palmicolous anamorphic genus and species, with some new records for the continental USA. Mycotaxon 107 (1), 357-373.

Goh T, Hyde K. 1998 - Spadicoides palmicola sp. nov. on Licuala sp. from Brunei, and a note on Spadicoides heterocolorata comb. nov. Canadian Journal of Botany 76 (10), 1698-1702.

Holubová-Jechová V. 1988 - Studies on hyphomycetes from Cuba VII. Seven new taxa of dematiaceous hyphomycetes. Ceská Mykologie 42 (1), 23-30.

Seifert KA, Morgan-Jones G, Gams W, Kendrick B. 2011 - The genera of Hyphomycetes. CBSKNAW Fungal Biodiversity Centre Utrecht,

Zhang YD. 2012 - Taxonomic Studies of Dead Wood Dematiaceous Hyphomycetes in Southern China. Master's thesis, Shandong Agricultural University, China

Zhao G, Liu X, Wu W. 2007 - Helicosporous hyphomycetes from China. Fungal Diversity 26 (2), 313-524. 